\title{
Analisis Risiko Penurunan Kinerja Keuangan UMKM (Studi Kasus Pada UD Asoka Paint)
}

\author{
Lola $^{1}$, Agustine Dwianika ${ }^{2}$ \\ ${ }^{1,2}$ Program Studi Akuntansi \\ ${ }^{1,2}$ Universitas Pembangunan Jaya, Tangerang Selatan, Banten 15413, Indonesia \\ Email : lola.1ola@student.upj.ac.id ${ }^{1}$, agustine.dwianika@upj.ac.id²
}

\begin{abstract}
ABSTRAK
Kinerja keuangan merupakan salah satu penentu keberhasilan suatu usaha, setiap usaha menginginkan kinerja keuangan yang optimal, begitupun Usaha Mikro Kecil dan Menengah (UMKM). Namun, mereka mengalami beberapa kendala yang menimbulkan risiko dan dapat menyebabkan penurunan kinerja keuangannya. Penelitian ini dilakukan untuk menemukan solusi menurunnya kinerja keuangan pada UD Asoka Paint. Tujuan dilakukannya penelitian ini yaitu untuk memperoleh hasil uji empiris mengenai risikorisiko yang dapat menurunkan kinerja keuangan UMKM. Metode pendekatan kualitatif dan teknik pengumpulan data berupa wawancara dilakukan untuk mendapatkan data primer serta analisis dokumen keuangan sebagai pelengkap data sekunder. Adapun hasil dari observasi ini menunjukkan bahwa UD Asoka Paint memiliki beberapa risiko yang dapat menimbulkan penurunan kinerja keuangannya. Pemilik belum melakukan pencatatan keuangan secara menyeluruh sesuai dengan standar akuntansi yang berlaku umum bagi UMKM. Pengatahuan akuntansi dan pajak bagi pengelola UD Ashoka merupakan solusi terbaik. Kedepan penelitian ini perlu dilengkapi dengan kegiatan pengabdian masyarakat yang bermanfaat bagi UD Ashoka, berupa pelatihan keuangan, kemudian melakukan analisa hasil setelah pelatihan tersebut.
\end{abstract}

Kata Kunci : UMKM, Kendala, Risiko, Pencatatan Keuangan, Kinerja Keuangan

\section{ABSTRACT}

Financial performance is one of the determinants of the success of a business, every business wants optimal financial performance, as well as Micro, Small and Medium Enterprises (MSMEs). However, they experience several obstacles that pose risks and can lead to a decline in their financial performance. This research was conducted to find a solution to the decline in financial performance at UD Asoka Paint. The purpose of this research is to obtain empirical test results regarding the risks that can reduce the financial performance of MSMEs. Qualitative approach methods and data collection techniques in the form of interviews were conducted to obtain primary data and analysis of financial documents to complement secondary data. The results of this observation indicate that UD Asoka Paint has several risks that can lead to a decline in its financial performance. The owner has not carried out comprehensive financial records in accordance with generally accepted accounting standards for MSMEs. Accounting and tax knowledge for UD Ashoka managers is the best solution. In the future, this research needs to be complemented with community service activities that are beneficial to UD Ashoka, in the form of financial training, then analyzing the results after the training.

Keywords: MSMEs, Constraints, Risks, Financial Records, Financial Performance 


\section{PENDAHULUAN}

Usaha Mikro Kecil Menengah (UMKM) merupakan salah satu komponen penting untuk memeratakan tingkat perekonomian rakyat. Menurut Undang-undang No. 20 Tahun 2008 yang ditetapkan pada tanggal 4 Juli 2008 yang mengatur tentang Usaha Mikro, Kecil, dan Menengah, adapun UMKM memiliki kriteria yaitu kekayaan bersih mulai dari Rp. 50.000.000,00 (lima puluh juta rupiah) sampai lebih dari Rp.500.000.000,00 (lima ratus juta rupiah) dan memiliki hasil penjualan tahunan mulai dari Rp.300.000.000,00 (tiga ratus juta rupiah) sampai dengan paling banyak Rp.50.000.000.000,00 (lima puluh milyar rupiah). Namun, selama ini banyak dari pelaku UMKM yang tidak melakukan pengelolaan keuangan dengan baik, mulai dari pencatatan hingga penyusunan laporan keuangan yang menyebabkan timbulnya risiko penurunan kinerja keuangannya. Adapun yang dimaksud dengan laporan keuangan ialah sebuah laporan yang berisikan informasi mengenai kinerja keuangan suatu perusahaan selama satu periode tertentu, yang menyajikan posisi keuangan, kekayaan, utang dan modal perusahaan dalam periode tertentu (Sulistyowati, 2017).

Sebagian besar UMKM hanya melakukan pencatatan sederhana yaitu pencatatan uang masuk dan uang keluar, bahkan ada pula yang tidak melakukan pencatatan keuangan. Pernyataan ini didukung dengan penelitian terdahulu yang dilakukan oleh (Wisnantiasri et al., 2018) dengan judul "Pelatihan Pembuatan Laporan Keuangan Bagi UMKM Sebagai Informasi Untuk Pengambilan Keputusan” pada penelitan tersebut diperoleh data dari 100\% pelaku usaha, hanya 29\% yang melakukan pembukuan, dan sisanya sebesar $71 \%$ tidak melakukan pembukuan. Tidak diakukannya pembukuan tersebut dikarenakan $60 \%$ pelaku usaha mengaku tidak menguasai cara pembuatan laporan keuangan dan 40\% mengatakan tidak membutuhkan pembukuan tersebut. Selain kendala dalam pencatatan keuangan, UMKM juga memiliki kendala lainnya, seperti akses keuangan. Akses keuangan merupakan kendala yang paling signifikan untuk menghambat perkembangan usaha. Selain itu, adapula kendala lain yang dialami pelaku UMKM seperti hambatan ukuran, usia, dan tingkat pertumbuhan usaha serta kepemilikan usaha. Kemudian adapula hambatan yang berasal dari pihak eksternal (Wang, 2016). Tidak diterapkannya pengelolaan keuangan yang baik juga terjadi pada salah satu UMKM yaitu UD Asoka Paint yang menjadi objek dalam penelitian ini. Tidak 
diterapkannya pengelolaan keuangan yang baik tersebut menyebabkan UD Asoka Paint memiliki beberapa risiko yang dapat menyebakan penurunan kinerja keuangannya. Risiko tersebut juga disebabkan tidak diterapkannya manajemen risiko. Beberapa permasalahan yang terjadi pada UD Asoka Paint diantaranya yaitu keuntungan yang cenderung kecil, adanya penumpukan persediaan yang membuat adanya persediaan yang usang dan tidak dapat lagi dijual sehingga menimbulkan kerugian, dan penurunan pendapatan akibat adanya Covid-19. Beberapa permasalahan tersebut terjadi pada UD Asoka Paint tentunya dapat mempengaruhi kinerja keuangannya. Kinerja keuangan merupakan unsur yang berhubungan langsung dengan pengukuran kinerja usaha secara keseluruhan. Biasanya kinerja keuangan dilihat dari laporan laba rugi dan penghasilan bersih untuk mengetahui bagaimana kondisi kinerja keuangan suatu usaha atau perusahaan (Fajrin \& Laily, 2016). Sedangkan dari sisi kinerja perusahaan secara keseluruhan, biasanya kinerja perusahaan seringkali dikaitkan dengan kepuasan pemegang saham dan keberhasilan perusahaan. Dalam persaingan bisnis saat ini, tidak mudah bagi suatu perusahaan untuk meningkatkan kinerja perusahaan baik dilihat dari aspek keuangan maupun non keuangan (Dwianika, 2020).

Adapun penelitian terdahulu yang dilakukan oleh (Sulistyowati, 2017) dengan judul "Pencatatan Pelaporan Keuangan UMKM Studi kasus di Kota Malang". Hasil penelitian menunjukan bahwa dari 50 orang responden, 35\% responden menyatakan tidak memahami tentang laporan keuangan. Penelitian terdahulu lainnya yang dilakukan oleh (Subroto et al., 2016) dengan judul "Analisis FaktorFaktor yang Mempengaruhi Kinerja Usaha Mikro Kecil dan Menengah (UMKM) Kabupaten Brebes". Hasil penelitian menunjukan bahwa terdapat pengaruh positif dan signifikan pada keuangan terhadap kinerja UMKM Kabupaten Brebes. Hal tersebut membuktikan jika kinerja keuangan sangat berpengaruh terhadap kinerja usaha secara keseluruhan. Untuk itu adanya penelitian ini dimaksudkan untuk memperoleh hasil uji empiris mengenai faktor-faktor yang dapat menyebabkan timbulnya risiko penurunan kinerja keuangan usaha dan memberikan solusi kepada UD Asoka Paint yang memiliki sejumlah permasalahan yang berkaitan dengan kinerja keuangannya, dan dengan diberikannya solusi tersebut diharapkan UD 
Asoka Paint dapat meningkatkan kinerja keuangannya dan dapat terus dikembangkan secara berkelanjutan.

\section{METODE PENELITIAN}

Adapun subjek penelitian ini merupakan salah satu UMKM yaitu UD Asoka Paint yang dimiliki oleh Bapak Cuncun. UMKM ini beralamat di Jl. Pondok Jagung Timur, Kp Dongkal Tangerang Selatan. UD Asoka Paint merupakan salah satu jenis usaha perdagangan yang menjual berbagai jenis dan merk cat serta komponenkomponennya. Sedangkan objek penelitian yaitu risiko penurunan kinerja keuangan yang dialami oleh UD Asoka Paint tersebut.

Jenis penelitian ini yaitu studi kasus, dimana peneliti menggali secara mendalam dan melakukan observasi tentang risiko yang akan menimbulkan penurunan kinerja keuangan yang dialami oleh UD Asoka Paint dan memberikan solusi atas masalah tersebut sehingga nantinya UD Asoka Paint dapat meningkatkan kinerja keuangannya dan dapat terus dikembangkan secara berkelanjutan. Penelitian ini menggunakan pendekatan kualitatif yang terbagi menjadi dua sumber data yaitu data primer dan data sekunder, data primer diperoleh dari hasil pengumpulan data menggunakan teknik wawancara kepada pemilik UD Asoka Paint dan data sekunder diperoleh dari hasil analisis dokumen pencatatan keuangan yang dimiliki UD Asoka Paint.

Adapun informasi yang digali melalui wawancara antara lain :

Tabel 1. Acuan Wawancara Kepada Narasumber

\begin{tabular}{|l|l|}
\hline \multicolumn{1}{|c|}{ Acuan } & \multicolumn{1}{c|}{ Pertanyaan } \\
\hline $\begin{array}{l}\text { Pemahaman tentang } \\
\text { akuntansi }\end{array}$ & $\begin{array}{l}\text { 1. Apakah memiliki pemahaman akuntansi } \\
\text { 2. Seberapa jauh mengenal akuntansi }\end{array}$ \\
\hline $\begin{array}{l}\text { Pemahaman tentang } \\
\text { pencatatan keuangan }\end{array}$ & $\begin{array}{l}\text { 1. Apakah mengetahui tentang pencatatan keuangan } \\
\text { 2. Apakah diperlukan pencatatan keuangan } \\
\text { 3. Apakah menerapkan pencatatan keuangan }\end{array}$ \\
& 4. Bagaimana pencatatan keuangan yang dilakukan \\
\hline Resiko usaha & $\begin{array}{l}\text { 1. Permasalahan apa yang dialami dalam usaha } \\
\text { 2. Bagaimana perkembangan usaha sejak pertamakali } \\
\text { didirikan }\end{array}$ \\
\hline
\end{tabular}

Sumber : Obseravasi kondisi usaha UD Asoka Paint 


\section{HASIL DAN PEMBAHASAN}

\section{Sistem Pencatatan Keuangan UD Asoka Paint}

UD Asoka Paint merupakan usaha perdagangan yang berskala kecil, lingkup dagangnya yaitu berapa jenis cat juga peralatan lainnya yang berkaitan dengan kegiatan mengecat seperti kuas, dempul, tiner, dsb. Karena merupakan usaha yang masih berskala kecil, sistem pencatatan yang dilakukan oleh UD Asoka Paint pun masih sangat sederhana, yaitu hanya laba rugi yang disusun setiap bulannya. Laba rugi yang disusunpun belum sesuai dengan laba rugi yang terdapat dalam laporan keuangan yang benar. Pemilik UD Asoka Paint hanya menghitung laba atau rugi dilihat dari pemasukan dan pengeluaran setiap harinya yang berhubungan dengan penjualan dan pembelian perlengkapan maupun persediaan yang diakumulasikan setiap bulannya. Lalu, pada pengeluaran untuk keperluan pribadi yang diambil dari keuangan usahapun tidak dilakukan pencatatan bahkan biaya-biaya yang berkaitan dengan usaha tidak dilakukan pencatatan. Selain itu, UD Asoka Paint juga tidak melakukan pencatatan mengenai persediaannya sehingga banyak persediaan yang usang dan tentunya menimbulkan kerugian.

Dengan sistem pencatatan keuangannya tersebut UD Asoka Paint memiliki kinerja keuangan yang kurang baik. Padahal, dalam wawancara yang dilakukan Pak Cuncun selaku pemilik usaha mengatakan bahwa adanya pencatatan keuangan yang baik tentunya sangat berpengaruh bagi usaha yang dijalankan. Karena dengan adanya pencatatan tersebut, dapat diketahui bagaimana keadaan usaha setiap periodenya. Pernyataan tersebut sejalan dengan penelitian yang dilakukan oleh Faaizah (2018) yang menyebutkan bahwa semakin berkembangnya usaha, tentu akuntansi sangat berguna untuk mengatur keuangan dan mengetahui laba rugi setiap periodenya agar dapat mengambil keputusan yang tepat. Tetapi dikarenakan keterbatasan pengetahuan yang dimiliki, akhirnya Pak Cuncun hanya melakukan pencatatan keuangan sederhana sesuai dengan kemampuannya. Peneliti juga melakukan analisis dokumen yang dimiliki oleh UD Asoka Paint berupa dokumen kas yang terdapat pencatatan kas masuk dan keluar dari transaksi penjualan barang dagang dan juga pembelian persediaan. Dari analisa tersebut diketahuilah alur pencatatan transaksi UD Asoka Paint.

Adapun alur pencatatan transaksi tersebut tergambar pada gambar berikut: 


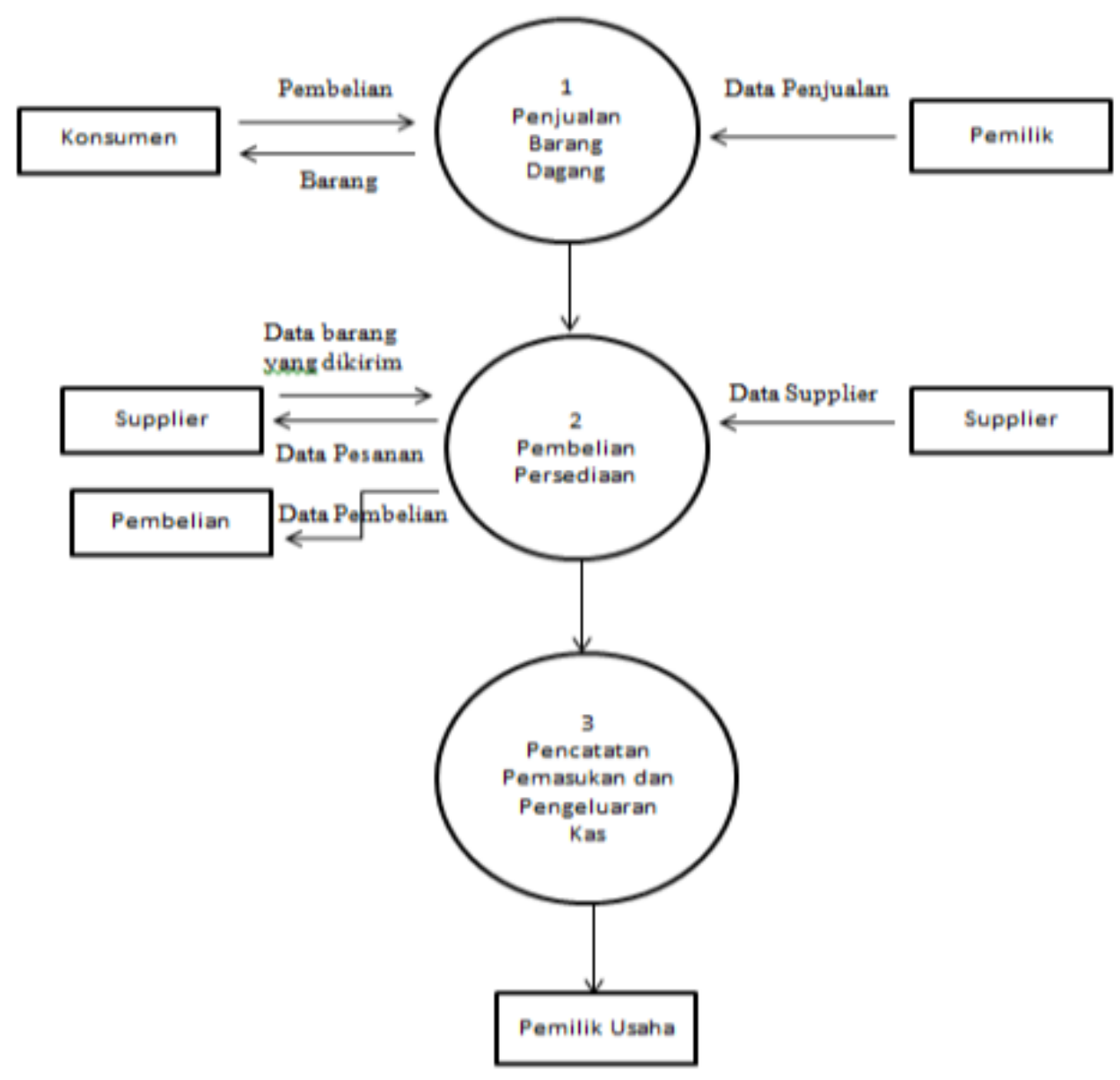

Gambar 1: Alur Pencatatan Transaksi

Sumber : Analisis Dokumen Keuangan UD Asoka Paint

Dari alur tersebut diketahui, terdapat tiga kegiatan keuangan yang biasanya terjadi pada UD Asoka Paint. Pertama yaitu penjualan barang dagang kepada para konsumen yang menghasilkan data keuangan berupa hasil penjualan. Kemudian yang kedua yaitu pembelian persediaan kepada supplier yang menghasilkan data keuangan berupa pengeluaran kas. Lalu yang terakhir hasil dari kedua transaksi sebelumnya diakumulasikan pada pencatatan pemasukan dan pengeluaran kas yang dilakukan oleh pemilik usaha setiap satu periode tertentu.

\section{Pembahasan}

Berdasarkan hasil wawancara yang telah dilakukan pada pemilik UD Asoka Paint, ditemukan beberapa permasalahan terkait risiko yang dapat menyebabkan penurunan kinerja keuangan pada usaha tersebut. Adapun masalah yang dialami yaitu keuntungan yang diperoleh cenderung kecil padahal pelanggan yang dimilki cukup 
banyak. Masalah tersebut terjadi karena beberapa hal yang berasal dari faktor internal dan eksternal. Faktor internal yang menyebabkan risiko penurunan kinerja keuangan diantaranya pendapatan yang dihasilkan terkadang digunakan untuk keperluan pribadi tanpa melakukan pencatatan, laporan keuangan yang dibuat hanya sebatas pencatatan pemasukan dan pengeluaran untuk mengetahui laba setiap bulannya dan tidak dilakukanya pencatatan persediaan untuk mengetahui jumlah persediaan yang tersisa.

Selama ini disaat melakukan pembelian persediaan barang dagang, pemilik hanya mengira-ngira persediaan apa yang menipis tanpa tahu jumlah pastinya dan hal tersebut tentunya menimbukan risiko. Risiko tersebut yaitu terdapat persediaan yang menumpuk menjadi usang dan tidak lagi dapat dijual sehingga menjadi suatu kerugian. Adapun risiko tersebut jika dilihat dari jenis sumbernya, maka risiko tersebut termasuk kedalam risiko internal karena berasal dari dalam usaha itu sendiri, yang disebabkan oleh pemilik usaha yang tidak melakukan pencatatan keuangan secara keseluruhan, jika dilihat dari sifatnya maka risiko tersebut termasuk kedalam risiko fundamental yang tidak dapat dilimpahkan kepada pihak lain dan tentunya harus diselesaikan sendiri oleh pemilik usaha tersebut

Adapula faktor eksternal yaitu terjadinya pandemik Covid-19 ini. Pendapatan yang dihasilkan menurun drastis dikarenakan berkurangnya pelanggan. Pendapatan anjlok bahkan hingga 50\%. Terjadinya wabah covid-19 ini termasuk kedalam risiko murni yang merupakan risiko yang tidak disengaja dan tidak terduga kedatangannya karena dapat dikatakan sebagai suatu bencana. Risiko tersebut juga semakin memperburuk keadaan keuangan UD Asoka Paint karena tidak adanya pengelolaaan keuangan yang baik. Faktor eksternal juga berasal dari kurangnya regulasi yang mengharuskan UMKM untuk melakukan pencatatan keuangan yang sesuai, lengkap dan tepat.

Dengan demikian, secara garis besar risiko penurunan kinerja keuangan UD Asoka Paint ini didominasi oleh faktor internal yaitu karena UD Asoka Paint tidak melakukan pengelolaan keuangan menyeluruh serta tidak diterapkannya manajemen risiko untuk menghadapi risiko-risiko yang tidak pasti sehingga menimbulkan risiko penurunan kinerja keuangan yang dimilikinya. Hal ini juga sejalan dengan sebuah penelitian yang dilakukan oleh (Lanang et al., 2014) ia menyebutkan bahwa faktor 
yang paling dominan mempengaruhi kinerja UMKM di Kabupaten Bangli adalah faktor internal.

Adapun alasan pemilik tidak melakukan penyusunan laporan keuangan yaitu karena kurangnya pengetahuan pemilik tentang bagaimana penyusunan laporan keuangan yang baik dan benar, padahal jika pemilik melakukan penyusunan laporan keuangan yang benar dan sesuai, pasti akan meningkatkan kualitas kinerja keuangannya yang dapat berpengaruh positif dan memberikan banyak manfaat bagi usahanya tersebut. pada penelitian ini juga sejalan dengan penelitian yang dilakukan oleh (Andrianto, 2016) dengan judul "Pencatatan Akuntansi Pada Usaha Mikro, Kecil, Dan Menengah (Umkm) Terhadap Implementasi Standar Akuntansi Entitas Tanpa Akuntabilitas Publik (SAK-ETAP) pada penelitian tersebut dinyatakan bahwa para UMKM tidak menerapkan akuntansi pada usahanya dikarenakan mengalami banyak kesulitan dan keterbatasan.

Berdasarkan paparan yang telah diuraikan terkait permasalahan yang terjadi pada UD Asoka Paint. Secara garis besar, solusi yang dapat diberikan peneliti mengenai risiko yang timbul dan dapat menyebabkan penerunan kinerja tersebut ialah dengan memperbanyak pengatahuan akuntansi dan pajak, lalu untuk memperbaiki kinerja keuangan UD Asoka Paint tersebut, solusi yang diberikan yaitu (1) Melakukan pencatatan persediaan dan mengupdatenya setiap hari untuk mengetahui persediaan yang ada sehingga tidak menyebabkan penumpukan persediaan yang akan berisiko kerusakan sehingga menimbulkan kerugian, (2) Memperbaiki pembukuan kas masuk dan keluar dengan mencatat secara keseluruhan kas masuk dan kas yang dikeluarkan termasuk untuk keperluan pribadi dan biaya-biaya lainnya yang berkaitan dengan keuangan usaha, (3) Menyusun laporan laba rugi yang benar untuk mengetahui bagaimana kondisi dan kinerja keuangan usaha sehingga dapat mengambil keputusan yang tepat untuk kelangsungan usaha diperiode selanjutnya, (4) Menerapkan manajemen risiko dengan menyiasati penjualan mengikuti keadaan yang sedang terjadi.

Cara menyiasati keadaan adanya virus ini bisa dilakukan dengan menjual barangbarang yang dibutuhkan oleh masyarakat, contohnya seperti masker kain, face shield dan hand sainitizer. Pemilik dapat membeli persediaan barang dagang tersebut pada e-commerce maupun bisa mencari informasi mengenai produsen atau tangan pertama 
yang menjual barang-barang tersebut sehingga dapat memperoleh harga yang lebih rendah untuk dapat menghasilkan keuantungan. Dengan demikian, penghasilan yang diperoleh setiap harinya dapat terbantu dengan penjualan barang dagang diluar barang dagang utama. Tetapi, meskipun dilakukan penjualan diluar penjualan barang dagang pada usaha utama tetap harus dilakukan pencatatan yang jelas. Laporan keuangan harus dibuat terpisah dengan laporan keuangan pada penjualan barang dagang utama, (5) Diharapkan pemilik UD Asoka Paint memperbanyak pengetahuan tentang akuntansi dengan mencari tahu dari buku-buku pengetahuan akuntansi, website, juga bisa mengikuti penyuluhan maupun seminar tentang akuntansi untuk UMKM sehingga nantinya dapat dilakukan penyusunan laporan keuangan berdasarkan SAK ETAP yang merupakan standar yang dibuat untuk mengatur tentang sistem pencatatan akuntansi UMKM

\section{SIMPULAN}

Berdasarkan penelitian yang telah dilakukan, diperoleh beberapa informasi terkait masalah keuangan yang dialami oleh UD Asoka Paint. Masalah tersebut timbul karena tidak dilakukannya pencatatan keuangan yang baik, serta tidak diterapkannya manajemen risiko. Hal ini menimbulkan risiko penurunan kinerja keuangan yang meliputi pendapatan yang cenderung kecil. Hal lain yaitu persediaan barang dagangan yang menumpuk, dan adanya kerugian akibat persediaan yang rusak dan penurunan penjualan yang signifikan akibat adanya Covid-19. Saat ini, UD Asoka Paint hanya melakukan pencatatan keuangan sederhana yaitu berupa laba rugi sederhana yang disusun setiap bulannya. Selain itu pencatatan keuangan tidak dilakukan secara keseluruhan, seperti pendapatan yang dihasikan sering digunakan untuk keperluan pribadi tanpa mencatat pada pembukuan yang ada. Hal tersebut tidak sesuai dengan kaidah pencatatan akuntansi yang berlaku umum. Sehingga terdapat risiko baik internal maupun eksternal di dalamnya. Berdasarkan sifatnya UD Asoka Paint juga memiliki risiko murni dan fundamental.

Penelitian ini berfokus pada UD Ashoka, sehingga hasil tidak dapat digeneralisir. Untuk itu diperlukan penelitian lanjutan yang mengkaji hal serupa dalam lingkup yang lebih luas, seperti lokal maupun nasional. Penelitian ini juga memerlukan sinergi dengan kegiatan pengabdian masyarakat berupa pelatihan keuangan bagi 
UD Ashoka. Kemudian dapat dilakukan pula penelitian pembanding sebelum dan sesudah dilakukannya pelatihan tersebut.

\section{DAFTAR PUSTAKA}

Andrianto. (2016). Pencatatan Akuntansi Pada Usaha Mikro,Kecil,Dan Menengah(UMKM) Terhadap Implementasi Standar Akuntansi Entitas Tanpa Akuntabilitas Publik (SAK-ETAP). Majalah Ekonomi_ISSN No. 1411-9501 _Vol. XX No. 2 Des 2016, XX(2 Des 2016), 185-192.

Dwianika, A. (2020). Pengaruh Water Awareness Terhadap Kinerja Perusahaan. Jurnal Wahana Akuntansi, 15(1), 15-24. https://doi.org/10.21009/wahana.15.012

Fajrin, P. H., \& Laily, N. (2016). Analisis Profitabilitas Dan Likuiditas Terhadap Kinerja. Jurnal Ilmu Dan Riset Manajemen, 5. http://jurnalmahasiswa.stiesia.ac.id/index.php/jirm/article/download/721/731

Lanang, I. P. E. S., Kirya, I. K., \& Cipta, I. W. (2014). Analisis Faktor-Faktor Yang Mempengaruhi Kinerja Usaha Mikro Kecil Dan Menengah (UMKM) Di Kabupaten Bangli. E-Journal Bisma Universitas Pendidikan Ganesha, 2(1), 11-21.

Subroto, S., Hapsari, I. M., \& Astutie, Y. P. (2016). Analisis Faktor-Faktor Yang Mempengaruhi Kinerja Usaha Mikro Kecil Dan Menengah (UMKM) Kabupaten Brebes. Prosiding SNaPP: Sosial, Ekonomi Dan Humaniora, 6(1), 337-344.

Sulistyowati, Y. (2017). Pencatatan Pelaporan Keuangan Umkm (Study Kasus Di Kota Malang). Referensi : Jurnal Ilmu Manajemen Dan Akuntansi, 5(2), 49. https://doi.org/10.33366/ref.v5i2.831

Wang, Y. (2016). What are the biggest obstacles to growth of SMEs in developing countries - An empirical evidence from an enterprise survey. Borsa Istanbul Review, 16(3), 167-176. https://doi.org/10.1016/j.bir.2016.06.001

Wisnantiasri, S. N., Sofia, I. P., Nurhidayah, F., \& Sunaryo, K. (2018). Pelatihan Pembuatan Laporan Keuangan Bagi UMKM Sebagai Informasi Untuk Pengambilan Keputusan. Jurnal Pemberdayaan Masyarakat Madani (JPMM) Vol 2 No 1 (Juli) 2018, 2(1), 63-82. 